Portland State University

PDXScholar

1977

\title{
The Therapeutic Community: Treatment as Viewed by Former Addicts
}

\author{
Barbara Ward \\ Portland State University \\ Robert York \\ Portland State University
}

Follow this and additional works at: https://pdxscholar.library.pdx.edu/open_access_etds

Part of the Social Work Commons

Let us know how access to this document benefits you.

\section{Recommended Citation}

Ward, Barbara and York, Robert, "The Therapeutic Community: Treatment as Viewed by Former Addicts" (1977). Dissertations and Theses. Paper 1905.

\subsection{0/etd. 1904}

This Thesis is brought to you for free and open access. It has been accepted for inclusion in Dissertations and Theses by an authorized administrator of PDXScholar. For more information, please contact pdxscholar@pdx.edu. 
THE THERAPEUTIC COMMUNITY: TREATMENT AS VIEWED BY FORMER ADDICTS

by

BARBARA WARD

ROBERT YORK

A practicum submitted in partial fulfillment of the requirements for the degree of

MASTER OF SOCIAL WORK

Portland State University 1977 
TO THE OFFICE OF GRADUATE STUDIES:

The Advisor approves the practicum of Barbara Ward and Robert York presented May 16, 1977.

Jack Finley, Advisor

APPROVED:

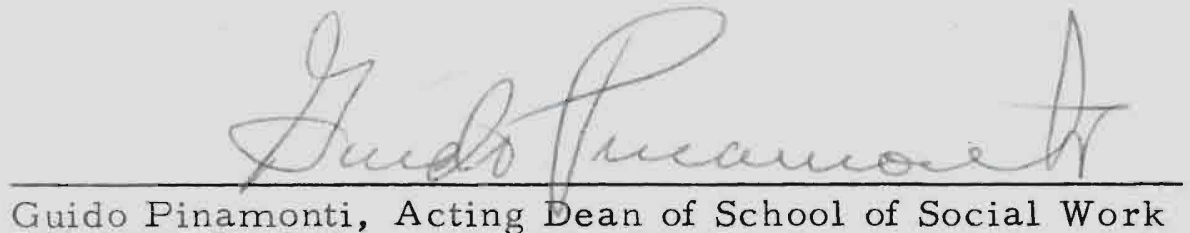

Date: 


\section{ACKNOWLEDGEMENTS}

We wish to acknowledge and thank the following persons who contributed to this study: Cary Herron, a friend who spent many hours with us developing the test instrument; and Jack Finley, Professor, School of Social Work, Portland State University, for giving us so much of his time, guidance, and encouragement.

Our special thanks and appreciation are extended to the twenty-three persons who were the subjects of our research, and who so willingly gave their time and cooperation to make this study possible. 
TABLE OF CONTENTS

PAGE

ACKNOWLEDGEMENTS $\ldots \ldots \ldots \ldots \ldots \ldots \ldots \ldots \ldots \ldots$ iii

\section{CHAPTER}

I INTRODUCTION $\ldots \ldots \ldots \ldots \ldots \ldots \ldots \ldots$

Statement of Purpose $\ldots \ldots \ldots \ldots \ldots \quad l$

History of the Problem ........... 3

II REVIEW OF THE LITERATURE ....... 13

III METHODOLOGY $\ldots \ldots \ldots \ldots \ldots \ldots \ldots \ldots, 28$

Subjects $\ldots \ldots \ldots \ldots \ldots \ldots \ldots \ldots \ldots \ldots \ldots \ldots$

Instrument $\ldots \ldots \ldots \ldots \ldots \ldots \ldots \ldots \ldots \ldots$

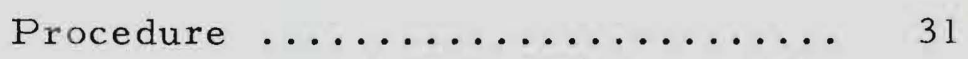

IV ANALYSIS OF DATA $\ldots \ldots \ldots \ldots \ldots \ldots .33$

Responses to Part A ............. 35

Responses to Part B ............ 43

V SUMMARY OF DATA $\ldots \ldots \ldots \ldots \ldots \ldots \ldots$

VI CONCLUSIONS $\ldots \ldots \ldots \ldots \ldots \ldots \ldots \ldots$

VII IMPLICATIONS FOR FURTHER STUDY ... 59

Limitations of the Study .......... 62 
CHAPTER

PAGE

BIBLIOGR A PHY

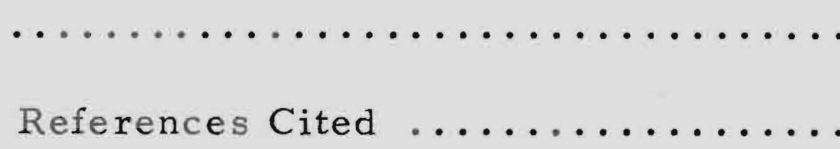

65

Additional Suggested Reading .......

65

APPENDIX

69

72 


\section{CHAPTER I}

\section{INTRODUCTION}

\section{STATEMENT OF PURPOSE}

The instant research effort is an outgrowth of the authors exposure to the field of drug treatment in general, and the rapeutic communities in particular. Both were acquainted with people who were graduates of therapeutic communities, and had been involved in many discussions concerning the relative merit of therapeutic communities as opposed to other methods of drug treatment.

It was noted that the literature on drug treatment often appeared to discount the effectiveness of therapeutic communities, (hereafter referred to as T.C.s), and disputed claims that T.C. graduates employed as counselors in drug treatment programs were, in fact, treatment successes. The available literature appeared to be primarily concerned with:

1. Attempts to describe addicts in terms of their common personality characteristics, social and economic backgrounds, and a variety of other factors, or

2. Attempts to describe, evaluate or compare various treatment modalities. 
There was virtually no information available in the literature concerning those individuals who had successfully graduated from T.C.s. Despite the criticisms of T.C.s, the authors felt them to be more effective than indicated by the credit they received. Discussion with acquaintances in the drug treatment field, and an examination of the literature, clearly demonstrated a lack of information regarding the graduates of such programs, and thus their actual effectiveness. This study was therefore developed to gain some subjective information from T.C. graduates regarding the perceived effectiveness of their treatment. In order to obtain the appropriate information, the authors decided on the formulation of an interview schedule to be used in personal interviews with as many T.C. graduates as feasible. This method seemed an appropriate vehicle for considering the value of T.C. programs, and generating material that would provide a basis for further research. The authors hoped through this study to:

1. Gain an idea of how T.C. graduates felt about their treatment.

2. Determine whether T.C. graduates viewed continuing contact with treatment programs after graduation, as an important aspect of their treatment.

3. Determine how T.C. graduates felt about the employment of ex-addicts as counselors, and the significance of this employment in their own treatment. 
4. Add to the meager literature concerning the employment of T.C. graduates as counselors.

5. Determine the implications for further study.

\section{HISTORY OF THE PROBLEM}

The use of opium and its derivatives is not a new phenomenon. Reference has been found as far back as 5000 B. C., when it was suggested that the Sumerians used opium (Lindesmith: 1968; p. 297). References to opium as a self-intoxicant, and its use in medicine are found in Egyptian, Greek, and Roman writings (Willis: 1973;

p. 38). Even as early as 2500 B.C. there is historical evidence to suggest that the Lake Dwellers of Switzerland ate poppy seeds (Montagu: 1966; p. 66). In 300 B.C., Theophrastus, a Greek naturalist and philosopher, recorded what has remained as the earliest undisputed reference to the use of poppy juice (Szasz: 1974; p. 184). Willis (1973; p. 1) states:

"F or many hundreds of years, even as far back as 2000 B.C. we find references to man's tendency to employ self-intoxication as a way of releasing himself from care and of insulating himself against the miseries of his existence. Nevertheless, it is mainly in the past 300 years that we find real evidence of widespread alcohol and drug abuse as constituting serious social problems."

In crude form, opium has been used in medicine for centuries. It was the first effective substance physicians found to relieve pain 
and produce sleep (Willis: 1973; p. 38). The danger of users becoming drug dependent was recognized by the ancient Romans, who referred to the hazards of chronic opium taking, and the ill-effects suffered when the taker was deprived of the drug. (Willis: 1973; p. 38). Despite this danger, the opiates have been extremely valuable in medicine. For many years opiates were all that physicians had to offer for the relief of pain(Willis: 1973; p. 25). Although the opiates' medicinal value is still unchallenged, the problems created by the potential for intentional or unintentional dependency and abuse have become abundantly clear. One of the basic tasks of experimental pharmacologists has been to try and develop powerful pain-relieving drugs which do not produce states of dependence. So far this has not been achieved (Willis: 1973; p. 25).

According to the literature there has always been a "drug problem" in the United States; although it has not always been a matter of widespread public concern (Morgan: 1974; p. 5). Opium smoking was the first form of addiction to receive public attention. This addiction was initially thought to be confined to certain segments of the population such as prostitutes, tramps, artists, and racial minorities who could be quarantined from the larger society with relative ease (Morgan: 1974; p. 8).

In the last 170 years, scientific inquiry has gradually isolated the active principles of opium, and has led to the synthesis of opiate- 
like drugs (Willis: 1973; p. 25). In 1805, Friedrich Wilhelm Adam Seturner, a German pharmacist, isolated morphine, the most potent of the alkaloids of opium (Szasz: 1974; p. 189). Both morphine and opium were freely used in patent medicines for the relief of headaches, insomnia, nerves, and a variety of other ailments throughout the 19 th century (Morgan: 1974; p 6). Morphine was sometimes sold as a cure for opium addiction, although some authorities claimed that it was more physically injurious, habit-forming, and difficult to cure than opium smoking (Morgan: 1974; p. 6).

Although there was a steady increase in drug use, public concern was not aroused until the 1870 s, when it became apparent that opiate addicts could be found in all levels of society (Morgan: $1974 ;$ p. 7). By that time, authorities estimated that only one-fifth of the opium imported went to legitimate medical channels (Morgan: $1974 ;$ p. 5). Despite the increasing evidence of abuse, in 1885 the Report of the Royal Commission on Opium concluded that opium was more like the Westerner's liquor than a substance to be feared and abhored (Musto: 1973; p. 29).

After the Civil War, the hypodermic syringe was widely used by physicians for the purpose of injecting morphine to combat pain. In 1864 , the first case of morphine addiction resulting from hypodermic medication was reported (Morgan: 1974; p. 7). Despite the reported danger, many physicians did not believe that narcotics were 
addictive when administered by injection; and they continued to use opiates indiscriminately in treating their patients (Morgan: 1974; p. 7). Hypodermic syringes were inexpensive, and readily available to addicts as well as physicians. Injections became increasingly popular, and were preferred by many addicts, since the effects of the drug were felt more rapidly and intensely than if ingested orally. Injections were also more convenient to use, since the need for cumbersome smoking equipment was eliminated (Morgan: 1974; p. 7).

In 1898 , heroin was synthesized from opium by the Bayer Pharmaceutical Company in Germany (Griffenhagen: 1968; pp. 16-28). Originally, heroin was regarded as a drug likely to be useful in the treatment of morphine addiction (Willis: 1973; p. 25, Griffenhagen: 1968; pp. 16-28). Heroin was found to be three times as strong as morphine, and faster acting (Morgan: 1974; p. 29). It was widely lauded by chemists as effective in treating respiratory problems. It also seemed to have potential as a sedative, and was initially considered as non-addictive (Willis: 1973; p. 25, Einstein: 1970; p. 4). Heroin was described by Montagu (1966; p. 68) as: "a safe preparation free from addiction-forming properties." In 1900, James R. L. Daly, writing in the Boston Medical and Surgical Journal, declared:

"It (heroin) possesses many advantages over morphine .... it is not hypnotic; there is no danger of acquiring the habit." (Quoted in Kolb: 1962; pp. 145-146). 
In 1906, Squibb's Materia Medica listed heroin as:

"..... a remedy of much value .....
it is also used as a mild anodyne and
as a substitute for morphine in combating
the morphine habit." (Lennard: 1973; p. 1079).

Heroin was cheap and readily available, and eventually it was

found in a variety of medicines such as cough syrups, asthma remedies, and sedatives. Until the first Pure Food and Drug Act was passed in 1906, it was possible to buy, in stores or by mail order, medicines containing morphine, cocaine, or heroin without their being so labeled (Szasz: 1974; p. 195). At the turn of the century, white addicts, $80 \%$ of whom were women, made up the bulk of the estimated 1,000,000 Americans addicted to opiates (Willis: 1973; p. 70). Many of them used drugs for primarily therapeutic purposes (Willis: 1973; p. 133), and were middle class people leading otherwise conventional family lives (Terry and Pellens: 1928; p. 23). For example, Dr. William Steward Halsted, one of the founders of Johns Hopkins Hospital in Baltimore, Maryland, established in 1889, was a morphine addict. Dr. Halsted used morphine in large doses throughout a phenominally successful surgical career lasting until his death in 1922 (Szasz: 1974; p. 192). Heroin had been in use for several years before it was found to be addictive; and although some local governments attempted to tighten controls, there was no national legislation to control the 
sale of opiates. Addiction was not considered to be a crime, but rather a medical problem to be treated by physicians (Nelkan: 1973;

p. 11). In 1912, the first International Opium Convention met at

The Hague, and recommended various measures for the international control of the opium trade. Subsequent conventions were held in 1913 and 1914 (Szasz: 1974; p. 196). In 1914, the Harrison AntiNarcotic Act was passed, putting the sale of opium and opium derivatives under federal control (Szasz: 1974; p. 198). One author of the day commented:

"I believe that most drug addiction today is due directly to the Harrison AntiNarcotic Act, which forbids the sale of narcotics without a physician's prescription ...... Addicts who are broke act as AGENTS PROVOCATEURS for the peddlers, being rewarded by gifts of heroin or credit for supplies. The Harrison Act made the drug peddler, and the drug peddler makes drug addicts." (Schless: 1925;p. 198)

Szasz (1974) states the view that:

"..... we had no problem with drugs until we quite literally talked ourselves into having one: we declared first this and then that drug 'bad' and 'dangerous '; gave them nasty names like 'dope' and 'narcotic '; and passed laws prohibiting their use. The result: our present problems of drug abuse and drug addiction $! . . .$. The plain historical facts are that before 1914 the re was no 'drug problem ' in the United States; nor did we have a name for it. Today there is an immense drug problem in the United States; and we have lots of names for it. Which came first: the 'problem of drug abuse' or its name." (Szasz: 1974; p. 11.) 
In discussing other effects of the Harrison Act, Willis (1973)

indicates that:

"The introduction of the Harrison Act in 1914 had the indirect effect of placing all drug users automatically outside the law, and it intensified the reluctance of doctors and social agencies to treat them. The only way in which a drug user could obtain a drug such as heroin was by illicit means, and in consequence a very intricate system of marketing drugs illicitly has developed, with all the ramifications and complex structure of a large industrial organization."

(Willis: 1973; p. 151).

Addiction in the United States peaked during the first two decades of the 20th century (Einstein: 1970; p. 4). Since the passage of the Harrison Act in 1914, the United States government has taken the position that self-medication and the use of certain drugs, (heroin, cocaine, marijuana, and hallucinogens) presents a social problem that necessitates federal, state, and local intervention (Einstein: 1970; p. 5). The Harrison Act was enacted in an effort to limit the production and trade of opium and opiates to the amounts necessary for medical and scientific use. Although ostensibly aimed at controlling addicts, the act was also effective in controlling physicians (Szasz: 1974; p. 150). It became unlawful to sell, barter, exchange, or give away opiates and cocoa products without an order written on a special form supplied by the Treasury Department (Einstein: 1970; p. 59). Opium and its derivatives became legally available only with a physician's prescription; however, physicians 
could continue using opiates in the treatment of their patients, and could also regularly prescribe them for addicts (Einstein: 1970; p. 59).

In a series of Supreme Court decisions following the passage of the Harrison Act, the courts ruled that the prescription of large amounts of opiates to addicts without attempting to cure addiction was unsound medical practice (Einstein: 1970; p. 59). These decisions resulted in a decrease in the number of physicians willing to prescribe drugs for addicts. In 1922, a further court ruling prevented physicians from legally supplying opiates to addicts for self-administration on the rationale that satisfying the addicts "craving" was outside the scope of legitimate medical practice (Szasz: 1974; p. 150). The implications were twofold: maintenance of addiction was forbidden, and addicts were not to be treated as outpatients (Einstein: 1970; p. 59). The social message was also twofold: addiction was wrong and evil, and addicts to be treated should be isolated from the community (Einstein: 1970; p. 60). No provisions were made for individuals already addicted, and suddenly they found that they were considered to be criminals, both in the eyes of the public and the law (Einstein: 1970; p. 59).

The manufacture of heroin was prohibited in the United States in 1924 (Szasz: 1974; p. 199). Since physicians could no longer supply opiates legally, a highly profitable new business developed around supplying addicts with illicit drugs (Morgan: 1974; p. 29). 
Although the cost of opiates increased dramatically with the enforcement of the Harrison Act, addicts had little difficulty obtaining opiates since well-developed underworld sources of narcotics were readily available (Morgan: 1974; p. 29).

In 1930, the Federal Bureau of Narcotics and Dangerous Drugs was established to attack the sources of heroin supply, and work toward the prevention of addiction (Interim Committee Report: 1972; p. 94). These tasks have not yet been accomplished. Heroin suppliers at the top of the line are well protected and difficult to reach. In a November, 1972, report to the Oregon State Legislature, the Interim Committee on Alcohol and Drugs reported that in the area of prevention through public education, the Bureau of Narcotics and Dangerous Drugs has taken a totally negative educational direction in frightening people with the real and imagined dangers of heroin use (Interim Committee Report: 1972; p. 94).

Since 1914, repressive anti-drug legislation has increased penalties, and widened the range of drugs covered by such penalties (Einstein: 1970; p. 60). The problems of criminality associated with drug use have been intensified to a considerable degree (Willis: 1973; p. 151), despite the faith legislators have placed in the deterrent value of criminal sanctions. The bulk of criminal behavior and physical illness associated with heroin addiction, appear to be more a result of the legal and social policies we espouse toward heroin, 
than they are a product of the drug itself (Interim Committee Report: 1972; p. 90). In September 1972, the Bureau of Narcotics and Dangerous Drugs applauded its own efforts by claiming that it had reduced the supply of illegal opiates on the streets to the extent that the street cost had doubled due to scarcity (Interim Committee Report: $1972 ;$ p. 90). As a result the addict had to steal twice as much, or otherwise obtain double funding, in order to maintain his habit.

Since drug abuse was labeled this nation's "public enemy number one" by Richard Nixon in 1972 (Levine: 1972; p. 1), little success has been noted in the war on drug abuse which has encompassed not only repressive anti-drug laws, but also the expenditure of considerable amounts of public monies. (Waldorf: 1973; p. 1) 


\section{CHAPTER II}

\section{REVIEW OF THE LITERATURE}

Synanon was the first therapeutic community (T.C.) in the United States (Yablonsky: 1965; p. 12). Since its establishment in 1958, Synanon has expanded considerably; and a number of other communities modeled after it have developed. Daytop Village began operating on Staten Island in 1963, as a halfway house for 25 addicts, all of whom were on probation (Casriel and Amen:1971; p. XVI). In 1967, Dr. Mitchell Rosenthal, a psychiatrist, established the Phoenix House program (Nash: 1974; p. 43). Dr. Rosenthal adopted many of Synanon's methods, and also hired a number of Synanon graduates to staff the program (Nash: 1974; p. 45). There have been a number of other T.C.S initiated since that time, both in the United States and abroad.

The philosophy of all T.C.s is basically one of informed and concerned self-help (Willis: 1973; p. 166). Drug use is recognized as an immature way of coming to terms with the world; and the addict is expected to make a strong commitment to living without drugs, and accepting the responsibility for his own behavior. Since the goal is to produce significant and lasting change in the individual, his stay 
in the community is likely to be lengthy if the desired changes are to occur. Synanon claims that many addicts are able to stay drug free as long as they remain in the contained community (Sutherland: 1968; p. 4, and Jaffe: 1969; p. 12).

The first T.C. to use graduates as ex-addict counselors was Synanon (Willis: 1973; pp. 166-167); although almost all such programs, including Daytop and the Phoenix Houses, currently employ ex-addict counselors (Smart: 1976; pp. 143-159, Sviland: 1974; p. 24, and Blachly: 1970; pp. 62-63). Some programs utilize only ex-addict counselors, i.e., Synanon, whereas others use both professional staff and ex-addict staff members. Due to the unusually high number ( $50 \%$ or more) of T.C. graduates employed in either their drug programs, other programs, or the social service field in general; and the small number of graduates returned to other types of employment (Smart: 1976; p. 156), the authors anticipated being able to find some written material pertaining to this phenomenon. There was, however, a paucity of information concerning T.C. graduates generally, as well as graduates employed as counselors in the mental health/drug treatment field.

Some writers have stated opinions to the effect that: "The ex-addict worker is best equipped to deal with the behavior of the addict patient." (Kadushin and Kadushin: 1969; pp. 386-393). Borenstein surveyed 126 methadone patients, and found that although 
they preferred to talk to physicians about methadone dosage, they preferred to talk to ex-addict counselors about their personal problems, or potential detoxification (Borenstein: 1964; p. 392). Borenstein noted: "The ex-addict worker was rated as the most significant influence outranking family and physicians, to remaining drug-free." (Borenstein: 1964; p. 393). Nash notes that of 35 Phoenix House graduates, 27 were employed in human service occupations, primarily in the field of narcotics addiction. He adds that almost all of these positions required leadership and adminis trative ability; and notes that in most cases training for these positions was acquired during the individual's participation in the Phoenix House program (Nash: 1974; pp. 42-63).

Campos describes two positions in which the ex-addict counselor may find himself in many drug treatment programs: He may be a barely tolerated fifth wheel, performing limited tasks under close scrutiny, and be treated as a flunky by the professional staff if they feel that "once a junkie, always a junkie." On the other hand, he may be given total program responsibility, and be treated as the only expert on the team because he once stuck a needle in his arm. Programs with this perspective seem to be staffed by people who feel that "only a junkie can treat a junkie," and that it is better to have been an addict and overcome the problem, than never to have been an addict at all. Campos suggests that neither of these 
two extremes is appropriate; and sees the ex-addict in a more viable role, as a full team member in a liaison position between staff and patient, where the gap in communication must be dealt with (Campos: $1964 ;$ p. 85).

The Mendicino Family encouraged residents to seek employment in the drug treatment field (Sherman: 1971; p. 15); and a substantial number of graduates were so employed (61\%) according to a study of graduates in 1972 (Glasscote, et al: 1972; p. 11). In a personal interview with the authors in January 1977, Mike Cline, a former senior coordinator of the Mendicino Family said:

'I wouldn't graduate anyone unless they had acceptable employment; and to me acceptable employment was a job in drug treatment or mental health."

In a personal interview with one of the authors in December, 1976 , Leonard Collette, director of Our Family, Inc. in Imola, California, stated:

"Employment of our graduates here (in Our Family) serves two purposes. It gives some members an added incentive, and it provides the program with trained employees." $\mathrm{He}$ added, "I don't see ex-addicts making any better counselors than straights; but at one time I did."

There are differences of opinion expressed by various writers in the field as to the appropriateness of T.C. graduates remaining in their communities as ex-addict counselors. One 
author writes:

"The author had initially disapproved of addicts remaining in the addiction system, i.e., working within their treatment program as "professional ex-addicts" in order to help others. He now believes it important that many exaddicts remain within the system, since this reinforces their own rehabilitation and growth, in the sense of differential association through the constant support of the facility and the reinforcements derived from helping others. " (Brill: 1973; p. 136).

On the other hand, Bullington, Munns and Geis note that:

"The marginal middle-class identification of the ex-addict counselor conflicting with his addict identification can create an unresolvable identity conflict. His close work association with practicing addicts hinders his deeper development of middle-class identity." (Bullington, Munns, and Geis: 1969; p. 458).

They also conclude that:

"To successfully identify with the non-addict culture the ex-addict counselor must reject his addict identity which requires emotional distancing of himself from the patients he helps ..... Administrative pressures to maintain a street style with patients, and daily association with addict patients hinders the total assimilation of non-addict identification. " (Bullington, Munns, and Geis: 1969; p. 460).

Sviland points out that the role of the ex-addict drug counselor is the only direct way that the ex-addict can enter the non-addict subculture, and be gently guided while learning its prescribed values and behaviors (Sviland: 1974; pp. 92-93). As ex-addict counselors help other addicts, they continually reaffirm their 
commitment to remain drug free, and ongoing relationships within the T.C. are equally important in serving this end (Sviland: 1974; p. 92, and Brill: 1972; p. 119).
"Identity resolution is at the core of the addiction problem. To successfully re- habilitate, the drug addict must shift his self-perceived identity from heroin addict to non-addict, and assimilate into a subculture that reinforces, rather than conflicts with this identity shift." (Sviland: 1974; p. 56).

Thus Sviland sees the efforts of ex-addicts to gain employment in the field of drug treatment, as a healthy attempt on their part to identify with the institution (Sviland: 1972; pp. 413-44)

Despite the fact that only $10-20 \%$ of all addicts are treated in T.C.s, (Adler, et al: 1973; p. 37) T.C.s represent the main drug free treatment approach to addiction. Unfortunately, there is little information available concerning T.C. graduates, since no controlled studies are available (Smart: 1976; p. 143), and no review of their success in rehabilitating addicts has been found in the literature (Smart: 1976; p. 144). Smart claims that T.C.s graduates are few in number, since only $6-15 \%$ of entrants actually complete their programs and graduate. Most of the studies of T.C. which have been undertaken, have been for the purpose of evaluating specific programs, and their focus is consequently extremely narrow (Waldorf: 1973; p. 135). Such studies have been primarily concerned with obtaining data on the number of people abstaining 
from the use of heroin following treatment, and the length of time involved in their abstention (Waldorf: 1973; p. 139). Studies which simply address themselves to whether a person is using heroin after treatment are bound to underestimate the results of treatment (Duvall, Locke, and Brill: 1967; pp. 8-9). T.C.s are quite rigid, in that they evaluate as successes only those persons who consistently remain drug free after graduation. Everything else is regarded as failure (Glasscote, et al: 1972; p. 20).

One of the difficulties involved in studying the effectiveness of any program is that persons who engage in treatment frequently do so on several occasions over an extended period of time (Brill: 1972; p. 119). It is therefore unwise to attribute abstinence to any one particular factor or treatment attempt. Earlier "unsuccessful" treatment programs may, in retrospect, be seen as having a significant, but delayed impact on an individual's abstinence (Brill: 1972; p. 119). A further problem involved in assessing the effectiveness of drug treatment programs, is that there are several different theories as to the causes of addiction; and these suggest different treatment approaches. Thus the issue of treatment becomes highly controversial.

One author commented that there appears to be considerable professional rivalry between the advocates of the various long-term treatment modalities for drug addicts (Willis: 1973; p. 168). Pro- 
ponents of both the major treatment modalities, i.e., therapeutic communities and methadone maintenance, appear to feel that they have resolved all the problems of addiction; and they are very closed-minded about programs other than their own as alternative methods of treatment (Waldorf: 1973; p. 127). Such theories or ideologies are strongly expressed in drug treatment programs, and the graduates of these programs frequently incorporate the ideology of their particular program into their personal philosophies to the extent that they reject all other program ideologies (Waldorf: 1973; p. 97).

Therapeutic communities espouse a psychological ideology, in that they consider the addict to be suffering from a character disorder. They claim that the addict is an immature, irresponsible child, who is unable to handle his own life, or the routine demands, pressures and frustrations of society (Hill: 1962; p. 97, Himmelsbach: 1974; p. 24, Sugarman: 1974; p. 128, Yablonsky: 1965; p. 82, Nash: 1974; p. 44, DeLeon: 1974; p. 211 , and Casriel and Amen: 1971; p. 136). Those who hold this view see drug addiction as symptomatic of underlying emotional problems. Treatment from this perspective involves not only abstinence from drugs, but also the restructuring of defective personalities (Nash: 1974; p. 45). The following statements are fairly typical of the attitudes of T.C. advocates toward methadone maintenance: 
"The latest attempt by professionals to cure heroin addiction - and one that has unfortunately received extravagant publicity - is the use of methadone. It is reminiscent of the way heroin itself was used at the turn of the century to treat morphine addiction."

(Casriel and Amen: 1971 ; p. XIII).

"I am utterly opposed to the indiscriminate use of methadone as a major treatment for drug addiction. Whatever the merits of the methadone program may be in "getting addicts off the streets," I don't see how we, as physicians, in all good conscience, can prescribe medication which is not curative, which itself is permanently addictive, when the re is indisputable evidence that there is a cure for the disease." (Casriel and Amen: 1971; p. XIV).

The major criticisms of methadone maintenance as a treatment method found in the literature, were that the methadone patient remains drug. dependent, and has merely substituted one drug dependence for another (Casriel and Amen: 1971; p. XIII, and Sviland: $1974 ;$ p. 66). Sviland also points out that the methadone patient's mobility is restricted to areas where the drug is available, his self-image is adversely effected by the fact that he continues to view himself as an addict, and he feels inadequate although he is able to function normally while taking the drug (Sviland: 1974; p. 64). Methadone programs do not plan to assist the stabilized, productive and well adjusted patient in detoxifying from methadone while retaining the support of the program (Waldorf: 1973; p. 128). Thus methadone patients are not given any hope for the eventual withdrawal 
from methadone and a drug-free life. Since these programs view addiction as a metabolic deficiency, they usually subscribe to the idea that methadone maintenance will be permanent (Glasscote, et al: 1972; p. 31). When a patient asks to be detoxified, this is usually seen as voluntary discharge from the program; and the patient is essentially abandoned by the program and given no further assistance (Waldorf: 1973; p. 126).

Methadone maintenance patients appear to have a somewhat lower relapse rate than patients treated in T.C.s (Sviland: 1972; p. 86), and while in the program they tend to be employed, have fair job satisfaction, and experience a decline in hustling and criminal activity (Waldorf: 1973; p. 122). They are not, however, encouraged to explore their motivations or behavior, since they are not considered to be suffering from a character disorder (Waldorf: 1973; p. 127).

A somewhat unconventional view of drug abuse is held by Szasz, who claims that there is no such thing as addiction, and calls the business of "addiction-mongering a gigantic hoax, a socially and professionally validated racket" (Szasz: 1974, p. 56). He points out that modern man attempts to deny the worth of the poppy, and even tries to annihilate its existence, despite the great debt that he owes it (Szasz: 1974; p. 65). He states that:

"When people find that a drug which they 
use to cope with life as they want to cope with it, hinders rather than helps them, they give up using that drug and give it up easily." (Szasz: 1974; p. 83).

Szasz points out that Freud and Malcolm X, both of whom were addicts, easily relinquished their drugs when using drugs was no longer expedient, or no longer served a purpose for them (Szasz: $1974 ;$ p. 83). He makes the following comments on the use of methadone:

"The use of methadone is considered to be a perfectly legitimate type of medical treatment for the heroin habit, while no mention is made of the fact that the use of heroin originated as a treatment for the morphine habit." (Szasz: 1974; p. 12).

"Traditional psychiatry has accepted the conventional definition of a certain type of behavior - the use of illegal drugs - as a type of disease falling specifically within the province of the "psychiatric physician." Having done so, all that remained for psychiatry was to establish its "etiology": a defect in the depth of the psyche; describe the course of the "untreated disease"; steady deterioration leading straight to the insane asylum; and prescribe its "treatment"; psychiatric coercion with or without the use of additional "therapeutic" drugs, (heroin for morphine, methadone for heroin, antabuse for alcohol)." (Szasz: 1974; p. 53).

In reviewing the professional literature, the authors noted that T.C.s have also been criticized for several reasons. Drug treatment requires considerable motivation on the part of the addict, and only a fraction of the addict population is motivated to enter T.C.S 
(Alternative Approaches to Opiate Addiction Control: 1972; p. 39). Selection processes further reduce this number, and the 12 month retention rate for those accepted is no more than $25 \%$ (Alternative Approaches: 1972; p. 40). A 1972 government study concluded that even if T.C.s were made widely available, admission requirements reduced, and no competing treatments existed, it is doubtful whether more than $10 \%$ of the addict population could be maintained in T.C.s. (Alternative Approaches: 1972; p. 40). The report stated that although T.C.s were not as effective as chemotherapeutic approaches in reducing the street addict population, they are nevertheless an important treatment modality, since for those addicts who find their approach acceptable, they produce good results at relatively low cost (Alternative Approaches: 1972; p. 41).

One of the major criticisms of T.C.s is that they do not in fact rehabilitate addicts to return to the community (Waldorf: 1973; p. 98). Waldorf feels that T.C.s implicitly, if not explicity, minimize the importance of preparing graduates to leave the program and return to the larger community, by encouraging graduates to work as counselors in drug treatment programs as part of their program ideology (Waldorf: 1973; p. 99). He accuses T.C.s of being anti-intellectual and anti-education, and claims that many programs do not encourage people to return to school, and do not utilize or develop job training programs. Some authors state that since 
T.C.s tend to be more wholesome, moral, and ethical than society in general, they are utopian, idealistic, and do not prepare people to deal with the outside world (Waldorf: 1973; p. 98, and Glasscote, et al: 1972). Waldorf expresses concern about how effective T.C.s are in rehabilitating addicts who must find adjustment to the outside world quite different from their expectations (Glasscote, et al: 1972 ; p. 52 , and Waldorf: 1973 ; p. 98). In response to this criticism, Jaffe states that:

"Experience demonstrates that many former compulsive drug users are able to remain drugfree and to function productively so long as they remain in residence. This is certainly a worthwhile achievement even if it falls short of the ideal of totally independent function in the community at large. Of all the approaches now under evaluation, however, this one may be best suited to yield that elusive, ideal, long-term goal of drug-free, productive behavior, without the need of continued medical or psychological treatment. It is also worth emphasizing that unlike the pharmacological approaches described for the treatment of narcotics use which are not relevant for the treatment of barbiturate or amphetamine abuse, the the rapeutic community concept is equally applicable to all forms of drug abuse." (Jaffe: 1970; pp. 62-63).

Some critics of T.C.s object to the heirarchical, authoritarian aspects of their structure, and the demeaning, punitive treatment of the residents (Glasscote, et al: 1972). They speculate that the high rate of dropouts from I. C.s might be related more to the se aspects of the programs, than to a lack of motivation on the part of the 
residents.

The authors have reviewed the literature extensively, and found that although a variety of theories are presented concerning drug abuse and treatment, there is little consensus of opinion. There appears to be general agreement that traditional psychiatric treatment methods are largely ineffective in treating drug addiction (Glasscote, et al: 1972; p. 40, and Casriel and Amen: 1971; p. 143). Much of the information available appears to be inconclusive, contradictory, speculative, and at times misleading. It seems clear that the standardization of rehabilitation criteria is needed to accurately assess the effectiveness of treatment programs (Sviland: 1974; p. 92). Some programs have loose criteria and consider only a full return to heroin as failure. Others have many strict criteria utilized in determining success and failure, including regular clinic attendance, decrease in arrests or illegal activities, absence of drug or alcohol abuse, productive employment or schooling, and satisfactory family or social interaction. It can be seen that there is no way of comparing treatment program effectiveness without uniform criteria (Sviland: 1974; p. 92). The lack of standardized criteria may account for the lack of information available in the author's chosen area of study. It is clear that there are no valid statistics as to the outcome of treatment, and the existing evidence does not permit us to determine with any validity, whether the 
current treatment methods are relevant to the problem of drug addiction. (Einstein: 1970; p. 58). 


\section{CHAPTER III}

\section{METHODOLOGY}

The study is of an exploratory nature. No hypothesis was. formulated since the purpose of the research was to gain more information on the attitudes of Therapeutic Community (T.C.) graduates concerning their own treatment, the importance of continuing contact with drug treatment programs, and the employment of ex-addicts as counselors.

\section{SUBJECTS}

The authors were unable to select subjects on a random basis due to the difficulties involved in identifying and locating a sufficient number of persons who met the criteria for inclusion in the study, and from whom a random sample of subjects could be drawn. Since the purpose of the study was to obtain information on the attitudes of T.C. graduates, it seemed appropriate to use an accidental sample even though the data obtained would not lend itself to statistical as sessment.

Through their work in the treatment field, the authors were personally acquainted with several ex-addict counselors currently 
working in treatment programs. With their help a list of graduates in the area who met the criteria and could be contacted personally was developed. Initially, the authors had a list consisting of 27 names of people who met the criteria established. The criteria were that each graduate interviewed had:

1. Successfully completed a minimum of 6 months residential drug treatment in a therapeutic community setting.

2. Completed such a program a minimum of 12 months prior to participation in the current study.

It was the author's intent to personally interview each of the 27 persons listed, providing that they could be located, and were willing to participate. Twenty-one of the 27 were located in the Portland-Vancouver area, and 6 were to be interviewed by one of the authors in Napa, California. In order to find enough subjects to interview it was necessary to have the freedom to go outside a single program or geographic area in order to find graduates who met the above criteria. It is doubtful whether this could have been accomplished without the assistance of counselors in the drug programs.

\section{INSTRUMENT}

The authors decided that personal interviews would yield more valuable attitudinal information than a questionnaire, and that 
this type of instrument would also be more specific than unstructured interviews, and hopefully ensure some similarity of interview focus and data obtained. An interview schedule was constructed by the researchers and revised several times in the interest of clarity. The interview schedule consisted of 2 parts, and each part contained both closed and open-ended questions. Many of the questions had 2 parts and required that the respondent initially give an answer to a closed-ended question by making a choice between alternate answers. He was then asked to explain his choice in an open-ended question.

Part $A$ of the interview schedule was designed to be applicable to all T.C. graduates. It contained 21 questions including questions on demographic information, questions about the graduate's personal treatment experiences, as well as his attitude toward treatment, and questions concerning education and employment. Part $B$ of the interview schedule was designed to be answered by only those graduates who were currently employed in the treatment field, or had been so employed in the past. Part B contained questions on the respondent's employment in the treatment field, his attitude toward the employment of ex-addicts as counselors, his attitudes toward his work and his attitudes toward "straight" staff members.

The interview schedule was pretested with two of the subjects, 
and their suggestions were noted. On the basis of these suggestions the interview schedule was again revised. Some questions were eliminated entirely due to redundancy, the sequence of questions was revised to group together questions that pertained to certain topics, and the wording of several questions was altered to improve clarity. A copy of the final interview schedule is included in the Appendix.

\section{PROCEDURE}

Each subject was contacted on an individual basis by the authors, either in person or by telephone. The authors introduced themselves, briefly explained the nature and purpose of the study, how the subject's name had been obtained and from whom, and then asked if the subject would be willing to participate in the study. Assurance of confidentiality was given at this point. If the subject indicated that he was willing to participate, an appointment was arranged, at his convenience, for the purpose of interviewing him. Each subject was interviewed individually. The questions were read aloud by the interviewer and the responses were written down by the interviewer, with one exception. In question 35 , the interviewer read the question aloud and then asked the subject to record his own responses since this involved ranking several items. The interviewer remained with the respondent to clarify when 
necessary. The time involved in completing each interview was approximately twenty to thirty minutes, depending on the verbosity of the subject's open-ended answers. Each subject was thanked for his participation at the end of the interview.

The authors were able to interview 23 of the 27 subjects selected. Six interviews were conducted in Napa, California; and 17 in the Portland-Vancouver area, giving the authors a total of 23 responses. For various reasons, 4 persons were not interviewed: 1 had permanently moved away from the area, 1 refused to be interviewed, and 2 could not be contacted for unknown reasons. The data was obtained from an accidental sample as previously noted, and therefore did not lend itself to statistical assessment due to the built-in bias of interviewing only T.C. graduates. The responses were therefore tallied by hand, and limited information on percentages, means and medians was calculated. The resulting information, in addition to the subjective responses given to open-ended questions, were not dealt with statistically but were presented in an interpretive manner. 


\section{CHAPTER IV}

\section{ANALYSIS OF DATA}

The authors originally obtained the names of 27 ex-addicts, and intended to interview each of them personally. Only $23(85.2 \%)$ of the graduates selected were, however, actually interviewed. Two $(7.4 \%)$ persons could not be contacted, $1(3.7 \%)$ had moved away permanently, and $1(3.7 \%)$ was contacted but refused to participate in the study. There were, therefore, 4 persons $(14.8 \%)$ not interviewed for various reasons. The response rate was fairly high, particularly in view of the population being studied. It was anticipated that ex-addicts might be both difficult to locate, and reluctant to participate in the study. The authors, therefore, relied heavily on ex-addict counselors in drug treatment programs to provide the names of other ex-addicts who met the criteria for inclusion in the study. The 23 ex-addicts originally selected did not all meet the criteria specified by the authors for graduates who were to be included in the study. The criteria were that each graduate interviewed have:

1. Successfully completed a minimum of 6 months residential drug treatment in a therapeutic community setting. 
2. Completed such a program a minimum of 12 months prior to participation in the current study.

One female respondent had spent 5.5 rather than 6 months in residential treatment, but was included in the study since she was one of very few female ex-addicts available to interview, and since she was a graduate and completed her program almost 4 years ago. A male graduate reported that 10 rather than 12 months had elapsed between leaving inpatient treatment and participating in the study. The authors were unaware of this until the interview was already in progress; the interview was therefore completed and the information utilized in the current study.

No data was collected on the respondents' current use of drugs. Since $56.5 \%$ of the interviewees were employed in drug treatment programs, the authors felt it unlikely that they would honestly answer questions on this topic. Regular and frequent contact with drug programs was reported by $82.7 \%$ of all individuals interviewed (including employees); and both peers and program staff viewed the respondents as drug-free. Due to their ongoing contact with these programs and each other, the graduates were not as difficult to locate as the authors anticipated. They we re also surprisingly willing to be interviewed in most cases; although the authors felt that often this was only because they either knew one of the authors personally, or had heard about the study through mutual acquaintances. 
Each respondent was assured of the confidentiality of the study.

The interview schedule was divided into two sections. Part A contained the questions numbered 1 through 21 , and was administered to all 23 of the respondents interviewed. Part B consisted of questions 22 through 35, and was administered to only the 19 respondents who had, at some point, been employed in the general field of mental health, or in drug treatment specifically. The following data is presented with this distinction in mind.

\section{RESPONSES TO PART A}

Questions 1 through 3 involved demographic data concerning the sex, age, and educational level of the 23 respondents. Of those interviewed, $19(82.6 \%)$ were male, and $4(17.4 \%)$ were female. The ratio of males to females was not significant since the sample was not a random one. The authors recognized that males significantly outnumber females in most drug treatment programs, as well as in the general addict population, and this is widely noted in the literature. An effort was made to locate and interview as many females as possible.

The respondents ranged from 25 to 46 years of age, with a mean of 32.04 years, and a median of 30 years for the entire group studied. Males had a slightly higher mean age of 32.79 years, whereas the females had a somewhat lower mean age of 28.5 years. 
This difference was due to the small number of females interviewed, all of whom were 30 years old or younger.

In terms of education, the respondents reported 8 to 15 years of schooling, with a mean of 12.6 years, and a median of 12 years of education. Only 2 persons (8. $7 \%$ ) had less than a 12 th grade education, and $11(47.8 \%)$ had at least 1 year of college. Ten respondents $(43.5 \%)$ had 12 years of education, $4(17.4 \%)$ claimed 1 year of college, $6(26.1 \%)$ claimed 2 years of college, and 1 person (4.3\%) reported 3 years of college. Twenty-one respondents $(91.3 \%$ ) had a minimum of a high school education. Questions 4 through 7 addressed themselves to objective treatment data. The responses to question 4 indicated that the interviewees had spent between 5.5 to 24 months in treatment as residents of therapeutic communities. The group had a mean of 13. 4 months, and a median of 12 months as residents. Females, with a mean of 13.9 months, had spent only a short time more in treatment than males (13.3 months) or the group as a whole.

In response to question 5 , the graduates indicated that they had been discharged from inpatient treatment for periods of time ranging from 10 to 81 months. The median length of time since residence was 39 months, although the mean for the group was 41.6 months. Males had a mean of 41.2 months which was similar to that of the entire group; whereas females had a somewhat higher 
mean of 43.5 months since residential treatment terminated.

Question 6 had to do with the length of time the interviewees spent in outpatient treatment after they left their various programs. Only $10(43.5 \%)$ of the 23 respondents had been treated on an outpatient basis, since not all the programs required treatment following discharge. Thirteen people $(56.5 \%)$ did not participate in outpatient programs. The 10 interviewees who did receive outpatient care, spent a mean number of 10.9 months in such treatment.

The interviewees' ${ }^{\prime}$ responses to question 7 indicated that the majority of the respondents, $20(86.9 \%)$, reported that they had made previous attempts at treatment, whereas $3(13.0 \%)$ stated they had not. The mean number of treatment attempts was 2 , although the median was 1 . The answers given by male and female respondents were not essentially different, in that the males had a mean of 2.1 previous treatment attempts, whereas 1.5 was the mean for females participating in the study.

Questions 8 through 11 were of a subjective nature, designed to elicit the respondents' personal attitudes toward their own treatment. In response to question 8,19 of the interviewees (82.6\%) stated that they did not feel any other type of treatment other than a therapeutic community would have worked for them. Two respondents $(8.7 \%)$ said they didn't know, and $2(8.7 \%)$ said they thought that other types of treatment would have worked for them. 
Interestingly, both of these last interviewees felt that shorter te rm residential programs would have been effective; but neither of them indicated that anything other than a somewhat modified form of therapeutic community would be an alternate, possibly effective form of treatment. Only 1 of the 2 suggested that a less rigid program in terms of discipline would have been effective for him. In response to question $9,20(86.9 \%)$ of the respondents, including all of the women, indicated that they did not feel they would have outgrown their need for drugs. Only $2(8.7 \%)$ felt they would have eventually outgrown this need, and 1 (4. 3\%) said that he did not know. It is clear that the majority of interviewees not only felt that they would not have outgrown their need for drugs without treatment; but also that they did not feel they would have succeeded in any type of treatment program other than a therapeutic community.

The majority of the interviewees answered question 10 affirmatively. Twenty-one (91.3\%), including all the female respondents, felt that treatment had created a significant change in their lives; only $2(8.7 \%)$ did not. A variety of explanatory responses were given by those who indicated that treatment had significantly changed their lives. The authors attempted to categorize these responses into the following 4 general types of change noted: 
1. Intrapersonal changes were most frequently cited by the respondents. The specific changes mentioned included gaining more insight, honesty, awareness, self-respect, freedom and self-confidence. Also mentioned were: getting in touch with feelings, liking self better, seeing self more realistically, and changing attitudes and values.

2. Environmental or concrete changes were also frequently cited. These included: changes in location, living environment and employment, as well as the acquisition of material goods (house, car, money, furniture), friends, health, opportunities and a different life-style.

3. Specific behavior changes were less often cited. These included staying away from drugs, expressing self better, viewing life more realistically, learning one's abilities and limits, and thinking more positively.

4. Perceptions of self prior to treatment were also given in response to this question. Comments were made such as: "I would have died - I was that sick;" "I had no money and only one change of clothes;" "I was on narcotics for eleven years and never had a place of residence;" "Every time I get an inkling to do some dope I think about my family and friends, and how depressed I used to be." Questions 11 through 13 addressed themselves to the number 
of regular contacts the respondents had with drug treatment programs, in what context these contacts occurred, and the respondents' attitudes as to whether such contact was important in keeping them clean after they left their therapeutic communities. Of the 23 respondents interviewed, 12 , including 1 female, (52.2\%) were employed as counselors in drug treatment programs, and 1 (4.3\%) was employed as the director of a drug program. Two people (8. $7 \%$ ) had regular contacts with programs as outpatients, $2(8.7 \%)$ had regular contacts with programs as visitors, and $2(8.7 \%)$ had regular contacts with programs to obtain support. Only 4 respondents (17.4\%) including 1 female, had no ongoing contact with a drug program.

In response to question 12 , the respondents reported a range of 0 to 7 contacts per week, with a mean number of 3.3 contacts weekly for each respondent. When the contacts were broken down with regard to the type of contact, the mean number of weekly contacts for employees was 5.15, for outpatients, visitors, and those wanting support, the mean number of weekly contacts was 1.5. The mean for the group as a whole was made higher by the unusually high percentage of employees interviewed (56.6\%). Responses to question 13 indicated whether the interviewees felt that regular contact with a program was important in keeping them clean. Eight respondents $(34.8 \%$ ) felt that regular contact 
was currently important in keeping them clean. Fourteen (60.9\%) stated that regular contact was important in helping them abstain in the past, and only $1(4.3 \%)$ felt that regular contact had never been an important factor in their abstinence. Ongoing regular contact with a drug program was felt by a number of the respondents to be of primary importance during the first year after leaving residential treatment.

On question 14, the respondents were almost evenly divided in their opinions as to whether employment in the mental health or drug treatment fields was encouraged by their therapeutic communities. Eleven (47.8\%) stated that employment of this type was encouraged, and $12(52.2 \%)$ said that it was not. In response to question 15 , as to whether employment of this type was required for graduation, only 2 respondents $(8.7 \%)$ felt that it was required, and $21(91.3 \%)$ felt that it was not. Of those who felt that it was required, $1(4.3 \%)$ felt that it was expressed, and $1(4.3 \%)$ felt that it was implied.

Questions 16 through 21 were addressed to employment and education. The responses made to question 16 indicated that 9 respondents (39.1\%) were attending school, and 8 of the 9 were in college. Of those in school, 3 were majoring in Psychology, 2 in Counseling, and 1 each in Sociology, Social Services, Business and Baking. Only 2, interestingly, were not 
receiving education in the helping professions.

The majority of the respondents stated, in response to question 17, that they were currently employed. At the time of the interviews, $19(82.6 \%)$ of the respondents were employed, and 4 $(17.4 \%)$ were not. Of those who were unemployed, $2(8.7 \%)$ were full-time college students not seeking employment, and 1 (4.3\%) had just terminated his employment voluntarily. Only 1 (4.3\%) of the respondents had been unemployed for 2 years after being fully employed for 5 years.

In response to question 18 , every respondent interviewed had been employed a minimum of 10 months since leaving treatment. The length of time graduates had been employed since treatment ranged from 10 to 72 months, with a mean of 35.6 months, and a median of 28 months. Responses to question 19 gave information on the type of employment currently held. Of the 19 respondents currently employed, $13(68.4 \%)$ were employed in drug programs (12 as counselors and 1 as a program director). One (5.3\%) was employed as a psychiatric technician, and $5(26.3 \%)$ were employed outside the human service field in auto mechanics, baking, bookkeeping, laminating and hospital housekeeping.

Questions 20 and 21 addressed themselves to the respondents' current job satisfaction, and their self-reported job skills. Of the 19 respondents currently employed, $18(94.7 \%)$ reported that they 
enjoyed their work, and only 1 person $(5.3 \%)$ said he did not like his job. Each interviewee reported between 1 to 8 different job skills, with a mean number of 3.65 and a median of 3 job skills per person. Skills in the construction area were most often cited, followed by skills in counseling. A wide variety of other skills were also reported by respondents including spray painting, baking, hairdressing, roofing, gandy dancing, fiberglass laminating, welding, and a variety of semi-skilled and unskilled jobs in which the respondents had been employed.

\section{RESPONSES TO PART B}

Questions 22 to 35 on the interview schedule were applicable only to those interviewees who were currently, or had in the past been employed in the mental health field generally, or drug treatment specifically, since completing their own drug treatment. Only

19 of the larger study group $(82.6 \%)$ were in this category, and responded to Part $B$ of the interview schedule.

In response to question 22 concerning the length of time the respondents had been employed in the mental health field, the 19 interviewees reported a range of 10 to 72 months. The mean number of months employed was 31.68 and the median was 27 months. The mean was high due to the fact that 7 people $(36.8 \%$ ) reported between 3 to 6 years of employment in this field. Two of the 
respondents $(10.5 \%)$ had been employed only in the mental health field, and never in drug treatment specifically.

Since 2 respondents $(10.5 \%)$ had not been employed in drug treatment, question 23 was answered by only $17(89.5 \%)$ of the 19 interviewees. A range of 3 to 72 months employment in the drug treatment field was reported by the 17 respondents. They had a mean number of 31.4 months, and a median number of 28 months employment in this field. The mean was again higher than the median due to 7 people $(41.2 \%)$ who reported from 3 to 6 years of employment in drug treatment. As might have been anticipated, little difference was noted in the length of time the respondents had been employed in these 2 related fields.

In response to question $24,2(10.5 \%)$ of the 19 respondents stated they had been employed in the mental health field prior to their treatment for addiction. Twelve $(63.2 \%)$ of the 19 respondents stated in response to question 25 that they had worked in jobs unrelated to mental health or drug treatment since their graduation, whereas $7(36.8 \%)$ had worked only in this field. Of the 12 who had worked at jobs unrelated to treatment since graduation, 8 $(66.6 \%)$ were currently employed in mental health or drug treatment, and $4(33.3 \%)$ currently held jobs unrelated to either field. Unfortunately, from the data obtained it was not possible to determine whether the 8 individuals now working in the treatment field had 
held their non-treatment related jobs prior to, or concurrent with, their current employment.

Question 26 sought information as to whether the respondents felt that the employment of former addicts as counselors was important to the success of a drug-treatment program and, if $\mathrm{so}$, in what way. Sixteen $(84.2 \%)$ of the 19 persons interviewed felt that the employment of ex-addict counselors was important to the success of a drug-treatment program, whereas $3(15.8 \%)$ did not. The respondents stated that ex-addicts had more insight into "dope-fiend behavior," and could relate better to addicts than "straight" staff members due to their personal experience of "having been there." They also felt that the success of a program was enhanced by the presence of ex-addict counselors as role models for the residents. The respondents made statements such as: "They have more rapport due to their common backgrounds;" "They provide an incentive for the residents to stay in the program;" "The addict knows he is talking to someone who has been there, and this reassures him." Some individuals made more vehement statements, such as: "One addict knows another - you can't ask a plumber to build a house;" $1195 \%$ of the help I got came from ex-addicts - the other $5 \%$ didn't have anything to do with staying clean;" "Ex-addict counselors can relate to both addicts and straight staff, and the refore have an advantage over straight staff members." One respondent said, "I 
don't think anyone but an ex-addict can reach a hard core drug addict. You don't psych him into change; you intimidate him into it." Another noted that the success of a program, and the success of an addict in staying clean were mutually dependent on the presence of ex-addicts as program counselors. He said that "Continued contact with the values, standards, and philosophy of a treatment program keeps people clean. If you keep people clean, the program succeeds."

In response to question $27,11(57.9 \%)$ of the respondents felt that the employment of ex-addicts as counselors in drug treatment programs was important to their success in remaining abstinent. Two respondents $(10.5 \%)$ did not feel that this was important in their remaining abstinent, and $6(31.6 \%)$ gave unspecific answers indicating that it was important for some people but not others, or that although it was helpful it was not essential for the ex-addict to work in drug treatment in order to maintain his abstinence.

Those who felt this type of employment was important to the abstinence of ex-addicts, gave primary reasons such as the additional support they receive in their jobs, and the fact that their work keeps them in touch with their past. Other reinforcement of abstinence is obtained from seeing addicts as they come in for treatment, hearing them talk about their lives in the street, being responsible to, and role models for, current residents in treatment, and "knowing that you have to go to work in a drug program the next 
day." Working in a drug program appears in itself to put some pressure on the individual to control his behavior. One respondent indicated that the support received from this type of employment was particularly important for graduates of programs which have no phase of gradual reentry into the community.

The majority of the interviewees, $18(94.7 \%)$ of the 19 , responded to question 28 by saying that they felt their treatment programs had trained them for their jobs. Only $1(5.3 \%)$ did not feel this way; however, this person was employed as a psychiatric technician and had never been employed in a drug treatment program. Question 29 asked whether the respondents felt that additional education or training would benefit them in their work. Seventeen $(89.5 \%)$ of the 19 individuals interviewed felt that they would benefit from additional education or training, whereas $2(10.5 \%)$ did not.

In response to question $30,8(42.1 \%)$ of the 19 respondents stated they viewed their jobs as part of their own treatment, whereas $11(57.9 \%)$ did not. Only $2(18.2 \%)$ of the 11 had never seen their work as part of their own treatment; $9(81.8 \%)$ had, in the past, viewed their jobs as part of their treatment. One interviewee stated that he considered his job as a part of his treatment for the first 6 months following his discharge from inpatient treatment. Sixteen $(84.2 \%)$ of the 19 persons answering question 31 , indicated that they saw their jobs in the mental health field as a way of staying 
in touch with people; but $3(15.8 \%)$ did not. Of the 3 who did not, 2 said they had at one time seen their jobs as a way of staying in touch with people, and 1 person did not respond to the question at all.

Question 32 was directed to whether the interviewees viewed their jobs as a way of staying in touch with the drug subculture. Twelve respondents $(63.2 \%)$ did not see their work as a way of staying in touch with the drug subculture, $6(31.6 \%)$ did see their jobs this way, and $1(5.3 \%)$ did not answer the question. One person commented that he could never get out of touch with the drug subculture. Of the 12 who did not see their work as a way of staying in touch with the drug subculture, $8(66.6 \%)$ said they had never seen their jobs this way, $3(25 \%)$ said they had at one time, ( 1 had felt this way during his first year of employment), and $1(8.3 \%)$ did not respond to the question.

In response to question 33,14 members of the group (73.7\%) saw themselves as different from "straight" staff members where they worked, but $5(26.3 \%)$ did not. A number of explanatory responses were given by those who saw themselves as different. The major difference noted was that "straight" staff members were not ex-addicts, and therefore had less knowledge about, and understanding of, the drug subculture. The respondents also felt that they related better to addicts, and had more awareness than their 
"straight" counterparts, although they stated that they were not accorded the same respect and consideration as "straight" staff. The "straight" staff were usually professionals with more formal education than the respondents, and the respondents felt they related on a more feeling level with addicts than the professionals, who they said, related on an intellectual level.

The ex-addict counselors expressed some strong feelings about the professionals in the drug treatment field, with regard to feeling somewhat threatened and put down by professionals who have the power, and control the programs. One person who was interviewed stated that he did not feel he was different, but had been made to feel that way by the professional staff. Another stated that he felt he was stigmatized, and not fully trusted by the professional staff; but was not sure whether this was due to his ex-addict status, or his lack of formal education.

Question 34 asked that the respondents state whether they saw themselves as having more, the same, or less dedication to treat addicts than "straight" staff members. Since 2 of the respondents $(10.5 \%)$ had been employed only in mental health, and not in drug treatment, only $17(89.5 \%)$ of the 19 interviewees responded to this question. Ten (58.8\%) of the respondents felt they had more dedication to treat addicts than "straight" staff, $6(35.3 \%)$ felt they had the same amount of dedication, and $1(5.8 \%)$ said 
he had less.

In the final question, the respondents were asked to rank 8 items in the order of most to least importance. These items were all benefits derived from employment in the treatment field. The respondents were in some agreement as to the items they felt to be the most and least important. Seven $(36.8 \%)$ of the 19 respondents stated that employment in the treatment field had been most important in helping them adjust to a new life style, whereas 5 $(26.3 \%)$ felt it had been most important in helping them stay clean. Helping others was the second choice of 6 respondents $(31.6 \%)$, and the third choice of 6 others (31.6\%); although only $2(10.5 \%)$ felt it was the most important item on the list. Gaining job security, and the opportunity to work with others were also felt to be important, particularly as second and third choices.

The least important item was felt by 8 people $(42.1 \%)$ to be staying in touch with the drug subculture; 5 respondents $(26.3 \%)$ also ranked this as seventh on the list of 8 items. Seven respondents $(36.8 \%)$ ranked making more money as either seventh or eighth on the list of 8 items, and 7 others (36.8\%) ranked gaining social status as either seventh or eighth on the list. These 3 items were seen as the least important of the benefits derived from employment in the treatment field. It should be noted that the respondents were in much greater agreement about what was least 
important than about what was most important, in terms of the benefits of employment in the treatment field. The respondents clearly selected 3 items as being least important; however, their selection of the items considered most important was more evenly scattered between 5 items. 


\section{CHAPTER V \\ SUMMARY OF DATA}

The authors found that the graduates interviewed had extensive experience both with drug use and drug treatment. They had an average of 2 unsuccessful treatment attempts prior to their successful treatment. They had spent between 13 and 14 months in residential treatment, followed by almost 11 months of outpatient care (in those cases where outpatient treatment was offered). An average of three and one-half years had elapsed since the interviewees were involved in treatment as patients.

In terms of demographic information, the graduates were primarily male $(82.6 \%)$, with a mean age of 32 , and a median age of 30. Only 2 lacked a high school education, and $39 \%$ were currently enrolled in school. Eighty-two percent of the interviewees were employed, and $68.4 \%$ of those employed (or $56.5 \%$ of the total group interviewed), were employed in drug treatment programs. All the interviewees, whether or not they were currently employed, had worked a minimum of 10 months since treatment. The mean number of months of employment since treatment ( 35.6 months), is probably not as accurate as the median of 28 months, due to the 
considerable length of time that several of the graduates had been employed. Those who were employed in the mental health/drug treatment fields reported an average of between 31 to 32 months of employment, although the median was between 27 to 28 months of employment in this field.

Almost half of the respondents $(47.8 \%)$ indicated they had received encouragement from staff members in their T.C.s to work in the mental health/drug treatment field, but did not feel that employment of this type was a requirement for their graduation. Regular ongoing contact with drug treatment programs was reported by the majority of interviewees $(82.6 \%)$, and $95.7 \%$ felt that regular contact with a program was important in helping them stay clean either currently or at some time in the past. The graduates felt quite similarly about therapeutic communities as was expected. They showed a strong bias in favor of this type of treatment program, and a somewhat negative attitude toward alternate forms of treatment. The vast majority of graduates $(82.6 \%)$ felt that no other type of treatment than a T.C. would have been effective for them, $86.9 \%$ indicated that they did not feel they would have outgrown their need for drugs without treatment, and $91.3 \%$ felt that their programs created significant changes in their lives.

It is clear from the responses of those graduates who had worked in the treatment field, that the majority $(84.2 \%)$ felt that the 
employment of ex-addicts as counselors is important to the success of a drug treatment program. Over half of the graduates $(57.9 \%)$ also saw this employment as important in helping them maintain their abstinence. A somewhat larger percentage (89.5\%) saw their jobs (either currently, or at some time in the past) as a part of their own treatment. The overwhelming concensus of opinion was that $94.7 \%$ of the graduates felt that their T.C.s had trained them for their jobs; although $89.5 \%$ felt additional education would benefit them in their work. Almost half of the ex-addict counselors $(47.4 \%)$ indicated that at some time they saw their jobs as a way of staying in touch with the drug subculture. This was seen as being the least important benefit of working in the treatment field, however, and their jobs were seen as more significant in helping them adjust to a new life style.

Interestingly, although $73.7 \%$ of those who had worked in treatment felt that they were different from "straight" staff members, only $52.6 \%$ felt they were more dedicated to treat addicts than "straight" staff. Some of the graduates expressed negative feelings about their relationships with "straight" staff members. They tended to feel that professional staff members had all the power and control in the programs, and resented this since they felt that as ex-addicts they were much better able to relate to and treat addicts. 


\section{CHAPTER VI}

\section{CONCLUSIONS}

In general, the authors found that the graduates interviewed showed a very strong bias in favor of therapeutic communities as an effective method of drug treatment. They tended to disregard any form of treatment which involved chemotherapy or which did not require long-term residential treatment. Since all of those interviewed had themselves graduated from T.C.s, and many were currently employed in such programs, the bias was expected. The responses given by these graduates then could not be generalized to a larger population of graduates who had different treatment experiences.

The majority of those interviewed felt that they would not have matured out of their addiction without treatment as has been suggested in the literature (Winick: 1962; pp. 8-17). They also indicated in the majority of cases that no other type of treatment would have been effective for them, and that their treatment had created a significant change in their lives. Those graduates interviewed in this study reported that their lives had undergone significant change in that they had been clean for an average of over three years, 
the majority were involved in stable employment and had been for an average of two to three years, and over one-third of them were currently attending college.

Most of the graduates had regular ongoing contact with drug treatment programs, although for many this was on an employee basis. They felt very strongly that regular contact with a program had been an important aspect of their treatment and helped to keep them clean at some point; however, over half felt this had been more important in the past than it was currently. Perhaps the maximum benefit of regular contact is obtained in the first year or so after graduation, and regular contact becomes less important as the graduate makes his adjustment to a different life style in the . community.

Over half of the interviewees we re employed in treatment, and almost half indicated that this type of employment had been encouraged in their T.C.s. The majority of those employed in the field felt that the employment of ex-addicts as counselors was important both for their success in staying clean, and the success of the program. Almost half of the counselors said they viewed their jobs as part of their own treatment, and all but two of the rest said they had previously felt that way. This suggests that perhaps the therapeutic benefit to be derived from employment in the treatment field may be maximized within a certain length of time, and after that, 
employment in the field is no longer as important in helping the exaddict to maintain his abstinence. The vast majority of the interviewees felt that their treatment programs had trained them for their jobs; and over half of them felt they were more dedicated to treating addicts than were "straight" staff members.

Although $36.8 \%$ of the graduates felt that working in the field had been most important in helping them adjust to a new life style, it was interesting to note that $73.7 \%$ stated that they saw themselves as being different from professional "straight" staff members. The differences noted were primarily in knowledge of the drug subculture, degree of self-awareness, and the quality of relationships with addicts. There were however some responses indicating that the interviewees felt stigmatized, not trusted, threatened by the professionals, and not treated equally in terms of respect and consideration. It seems fairly safe to assume that if the se feelings exist among ex-addict staff members generally, they must have a negative influence upon the cohesiveness of the treatment team, and hence the effectiveness of treatment. Further exploration of this subject seems indicated to determine whether, and to what extent, ex-addict counselors have these feelings. Perhaps it would also be of value to explore the feelings of the professional staff toward such counselors.

In an effort to determine whether ex-addict counselors worked 
in the treatment field due to a lack of other marketable employment skills, the authors inquired of each graduate how many other skills he or she had? Although some respondents reported few skills, others reported many, and the average number of job skills per interviewee was 3.65. This suggests that for the population studied at least, the graduate who is employed as a counselor has other job skills with which to gain alternate employment should he choose to do so. Further research in this area is needed before any general statements can be made as to why a number of graduates gain employment in the treatment field. It does appea $r$ that they are encouraged toward this type of employment by their treatment. 
CHAPTER VII

\section{IMPLICATIONS FOR FURTHER STUDY}

The authors are aware that therapeutic communities treat only 10 to $20 \%$ of the addict community (Adler, et al: 1973; p. 17), and return only a very small number of rehabilitated addicts to the community (Brill: 1972; p. 143). Few addicts have the motivation to volunteer for treatment in T.C.s, a number of those that do are screened out by the selection procedures, and the retention rate over a 12 -month period for those accepted is no more than $25 \%$ (Alternate Approaches to Opiate Addiction Control: Costs Benefits and Potential 1972). Despite these discouraging statistics, the authors feel that T.C.s are an innovative and viable method of treatment for addicts who desire abstinence as opposed to chemotherapy. T.C. s are a viable method of treatment in terms of cost. The expense of operation is relatively low since the re are often only a few salaried employees needed. They operate on a self-help principle. This means that those who have graduated from such groups have learned to deal with their own problems better than they used to, and at the same time, have learned to give help to others in various carefully defined ways which are built into the culture of the T.C. 
Therefore, older residents are expected to help not only themselves but also newer residents, thereby reducing the need for many paid staff. As our interviewees indicated, they learned their counseling skills as part of their treatment; and they not only learned to abstain from drugs, but were taught a new way of life based on honesty between people, and responsible concern for one another. They learned to change many of their basic attitudes and values in addition to their self-destructive behavior.

Research on the graduates of T.C. $\mathrm{s}$ is meager as the authors have previously noted. The limited information which is available has as its focus only the length of time individuals have been abstinent, and fails to consider other factors which have been modified by treatment. It would appear useful to pursue further the views of graduate ex-addicts in order to determine more precisely what changes they made through treatment, and what aspects of their treatment they found useful. A more comprehensive and scientifically controlled study involving all aspects of the graduate's life would be of great value in improving current methods of treatment. The authors note the tremendous rivalry that appears to exist between proponents of the different methods of treatment, and the way in which program graduates appear to incorporate into themselves the ideology of their program and reject any other form of treatment as invalid. This gives treatment a mystical quality, 
and precludes cooperation and a mutual sharing of ideas to improve treatment in the field of addiction.

Information obtained in the current study suggests that regular contact with a drug program, and employment in the field of drug treatment are important supports for the new graduate, and are beneficial in helping him through the first year or so of abstinence. Their importance appears to diminish as the length of time since discharge increases. This leads to some speculation as to whether there comes a time when the graduate no longer needs contact with a program or to be identified as an ex-addict, and might in fact prefer not to be so identified once he has regained control of his life, and reestablished himself in the community.

Although it appears that graduates are encouraged toward employment in the treatment field, further information is needed to determine their motivation for doing this type of work, since there are undoubtedly several factors involved. Since a tremendous number of graduates do find employment as counselors in drug programs, it would seem appropriate for further research to be addressed to not only their motivation for doing so, but also to the effect of continuing contact with a program (either as an employee or a visitor) after the first year or so when the maximum the rapeutic benefit has been attained.

Finally, the authors would view as useful further investigation 
into the reported differences graduates saw between themselves and "straight" or professional staff members. If ex-addict counselors generally are found to have the negative feelings reported by those in the current study, further exploration of these feelings, as well as the feelings of professional staff toward ex-addict counselors would be in order. If there are unresolved negative feelings adversely effecting the cohesiveness of treatment staff in many drug treatment programs, an effort should be made to resolve this problem, and thereby improve the relationships between staff, and the quality of treatment available in their programs.

\section{LIMITATIONS OF THE STUDY}

The research design proved to be appropriate for the data that the authors sought to obtain. Both objective and subjective data were yielded by the test instrument. The instrument was, however, unclear in several areas and would have benefitted from further refinement for improved clarity and specificity. On several questions the respondents sometimes requested further clarification before being able to provide the authors with the specific information needed. A further problem noted was that respondents sometimes gave "yes" answers and continued to elaborate on them until it became clear that their answers actually were "no" rather than "yes" answers. Whether this was due to a problem in the test instrument 
itself, or whether the subjects had more difficulty comprehending questions which they heard rather than saw directly, is unknown at this point.

The test instrument did appear to elicit the subjective responses required by the open-ended questions quite well, and much valuable information was obtained in these responses. Questions 10 , 32, and 35 were not, however, worded clearly enough in the opinion of the authors, and question 31 appears to have been so ambiguous as to have served no useful purpose. Question $31 \mathrm{might}$ well be completely eliminated from the interview schedule without detriment to the study.

The current study was limited largely by the focus of the study, which was to investigate the attitudes of T.C. graduates. Since T.C. graduates are relatively few and far between, it was necessary to go beyond the limits of any 1 program in order to locate a sufficient number of them that could be personally interviewed for the present study. Consequently, the subjects interviewed came from 4 different treatment programs, including 2 about which relatively little was known other than that they were acknowledged as T.C.s. Although the authors were interested in individual attitudes rather than similarities and differences between programs, these cannot be completely ignored. Persons subjected to different experiences might be anticipated to have different attitudes as a 
result of those experiences. In the authors' opinion, the current research might have proved more significant had it been possible to study graduates of only 1 program, since in a study group of this type it would appear more likely that the subjects would have had a more uniform experience in terms of their drug treatment.

Had it been possible to restrict the research to 1 particular drug treatment program, the authors would have been able to gain some familiarity with that program's operation and ideology. It would also have been feasible perhaps to consider treatment failures in addition to treatment successes, or to obtain comparative data for "old" as opposed to "newer" graduates. Despite the limitations of the study, the authors feel that valuable information was obtained on T.C. graduates, their attitudes and their employment as drug counselors, and feel that the research will be helpful in adding to the meager literature available on such individuals. 


\title{
BIBLIOGRAPHY
}

\author{
REFERENCES CITED
}

Adler, F., Moffett, A.D., Glaser, F.B., Ball, J.C., and Horowitz, D. The Treatment of Drug Abuse in Pennsylvania. Harrisburg, Pennsylvania: The Governor's Council on Drug Abuse, 1973.

Blachly, Paul. Drug Abuse: Data and Debate, Chicago: Charles C. Thomas, 1970.

Borenstein, D. "The Relative Value of the Medical Staff Versus Addicts in Rehabilitation of the Drug User in a Drug Abuse Program," Proceedings of the Fourth Methadone Conference of the National Association for the Prevention of Addiction, 1964.

Brill, Leon. The De-Addiction Process, Springfield: Charles C. Thomas, 1972.

Bullington, B., Munns, J.G., and Geis, G. "Purchase of Conformity: Ex-Narcotic Addicts Among the Bourgeoisie," Social Problems, Nov. 1969.

Campos, R. L. "Staff Training for Supportive Services," Proceedings of the Fourth Methadone Conference of the National Association for the Prevention of Addiction, 1964.

Casriel, Daniel and Amen, Grover. Daytop: Three Addicts and Their Cure, New York: Hill and Wang, 1971.

Cline, Michael. Former Senior Coordinator of the Medicino Family, Ukiah, California. Interview, January, 1977.

Collette, Leonard. Director of Our Family, Inc., Imola, California Interview, December, 1976.

DeLeon, George, Ed. Phoenix House: Studies in a Therapeutic Community, 1968-1973. New York: M.S.S. Information Corporation, 1974. 
Duvall, H. J., Locke, B., and Brill, L. "Cyclazocine Intervention in the Treatment of Narcotics Addiction," The Bulletin, N.Y.S. District Branch, American Psychiatric Association 10 (January, 1967): 8-9.

Einstein, Stanley. The Use and Misuse of Drugs: A Social Dilemma, Belmont, California: The Wadsworth Publishing Co. 1970.

Glasscote, R., Sussex, J.N., Jaffe, J.H., Ball, J., and Brill, L. The Ireatment of Drug Abuse: Programs, Problems, Prospects, Washington, D. C.: The Joint Information Service, 1972.

Griffenhagen, G.B. "A History of Drug Abuse," Journal of the American Pharmaceutical Association, NS 8:1 (1968): $16-28$.

Hill, H.E. "The Social Deviant and Initial Addiction to Narcotics and Alcohol," Quarterly Journal of Studies in Alcohol, 1962.

Himmelsbach, Clifton K. "Opiate Addiction," in Types of Drug Abusers and Their Abuses, by John G. Cull and Richard E. Hardy, Springfield, Illinois: Charles C. Thomas, 1974.

Jaffe, Jerome H. "Development of a Successful Treatment Program for Narcotics Addicts in Illinois," in Drug_Abuse: Data and Debate ed. Paul Blachly, Chicago: Charles C. Thomas, 1970.

Kadushin, L. and Kadushin, A. "The Ex-Addict as a Member of the Therapeutic Team," Community Mental Health Journal, $5(1969): 386-393$.

Kolb, Lawrence. Drug Addiction: A Medical Problem, Springfield, Illinois: Charles C. Thomas, 1962.

Lennard, Henry. "Methadone Treatment," Science, 179 (March 1973): $1078-1079$.

Levine, Francis. "Nixon Focuses on Drug Fight," Syracuse Herald Journal, March 20, 1972.

Lindesmith, Alfred. Opiate Addiction, Bloomington, Indiana: Principia Press, 1968.

Montagu, Ashley. "The Long Search for Euphoria," Reflections 1 (1966): 62-69. 
Morgan, H. Wayne, ed. Yesterday's Addicts: American Society and Drug Abuse 1865-1920, Norman: University of Oklahoma Press, 1974.

Musto, D.F. The American Disease: Origins of Narcotic Control, New Haven: Yale University Press, 1973.

Nash, George. "The Sociology of Phoenix House: A Therapeutic Community for the Resocialization of Narcotic Addicts, "in Phoenix House: Studies in a Therapeutic Community (19681973), ed. George DeLeon, New York: M. S. S. Information Corporation, 1974.

Nelkan, Dorothy. Methadone Maintenance: A Technological Fix, New York: George Braziller 1973.

Report of Interim Committee on Alcohol and Drugs, Oregon State Legislature, November, 1972.

Schless, Robert. "The Drug Addict," American Mercury, 4 (February 1925): 196-199.

Sherman, Scott L. "Drug Abuse Rehabilitation: A Participant Observer's Description of the Family A Self-Help Program," Drug Forum 1 (4) (1972): 335-355.

Smart, Reginald G. "Outcome Studies of Therapeutic Community and Halfway House Treatment for Addicts," The International Journal of Addictions, 11 (1) (1976): 143-159.

Sugarman, Barry. Daytop Village: A Therapeutic Community, New York: Holt, Rinehart and Winston, Inc., 1974.

Sutherland, H. "The Synanon House of Cards: Deck is Stacked for Recovery," Los Angeles Times, October 6, 1968.

Sviland, Mary Ann, "The Ex-Addict and His Alternative Subcultures," in Types of Drug Abusers and Their Abuses, by John G. Cull and Richard E. Hardy, Springfield, Illinois: Charles C. Thomas, 1974.

Sviland, Mary A. "The Heroin Addict on Methadone Maintenance: His Attitudes, Resistance to Psychotherapy, and Identity Problems," Proceedings of the 80th Annual Convention of the American Psychological Association, N.P., 1972. 
Szasz, Thomas. Ceremonial Chemistry: The Ritual Persecution of Drugs, Addicts and Pushers, Garden City, N.Y.: Anchor Press/Doubleday, 1974.

Terry, C.E. and Pellens, N. The Opium Problem, New York: Bureau of Social Hygiene, Inc., 1928.

U.S. Department of Justice, Bureau of Narcotics and Dangerous Drugs. Alternative Approaches to Opiate Addiction Control: Costs, Benefits and Potential, Washington, D. C. : Government Printing Office, 1972.

Waldorf, Dan. Careers in Dope, Englewood Cliffs, New Jersey: Prentice-Hall, Inc., 1973.

Willis, James. "Drug Dependence: Some Demographic and Psychiatric Aspects in U.K. and U.S. Subjects, "British Journal of Addiction, 64, 1969.

Willis, James. Addicts: Drugs and Alcohol Re-examined, London: Sir Isaac Pitman \& Sons, Ltd., 1973.

Winick, C. "Maturing Out of Narcotic Addiction," Bulletin on Narcotics, 14 (1) (January-March 1962): 1-7

Yablonsky, L. The Tunnel Back: Synanon, New York: MacMillan Co., 1965. 


\section{ADDITIONAL SUGGESTED READINGS}

Bewley, T.H. "Recent Changes in Patterns of Drug Dependence in the U.K."" Bulletin of Narcotics, 28 (1) (1966).

Blum, Richard. Drugs I: Society and Drugs, San Francisco: JoseyBass, Inc., 1969.

Brecher, E.M. Licit and Illicit Drugs, Mt. Vernon, New York: Consumers Union, 1972.

Brewster, John T. "Let's Diagnose Ourselves," Canada's Mental Health, $20(6)$ Nov. -Dec., 1972.

Brewster, John T., Charles Garrigues. "The Mendocino Game Rules, Policies, Modes and Techniques," Drug_Forum, 4(1) $(1974): 15-29$

Brill, Leon. "Drug Abuse as Social Problem," International Journal of the Addictions, 4 (2) Fall, 1966.

Brill, Leon. Some Comments on the Paper "Social Control in Therapeutic Communities," by Dan Waldorf, The International Journal of the Addictions, 6(1) March, 1971.

Chein, I., Gerard, D.L., Lee, R.S., and Rosenfield, E., Narcotics, Delinquency, and Social Policy - The Road to H. Tavistock, London, 1964.

Carroll, Jerome. Is the Addict Or Alcoholic Mentally Ill, Paper presented at the Seventh Annual Eagleville Conference, Eagleville, Pa., 1974.

Dai, B. Opiate Addiction in Chicago, Shanghai: The Commercial Press, 1937.

Eldridge, William B. "Narcotics and the Law," New York: American Bar Foundation, distributed by N. Y. University Press, 1962.

Fischmann, Vitezslav S. "Drug Addicts in a Therapeutic Community," The International Journal of the Addictions, 3(2) Fall, 1968. 
Glatt, M. M. , Pittman, D.J., Gillespie, D. G., and Hills, D. R. The Drug Scene in Great Britain, London: Edward Arnold, 1967.

Goldstein, Avram. "Heroin Addiction: Sequential Treatment Employing Pharmacologic Supports," Archives of General Psychiatry, 33 (1976): 353-358.

James, I.P. "Suicide and Mortality Amongst Heroin Addicts in Britain," British Journal of Addiction, 62 (1967): 277.

Jones, Maxwell. The Therapeutic Community, New York: Basic Books, 1953.

Kasviner, A., Mitcheson, M. C., Myers, K., Ogbourne, A., Stinson, G. V., Zacune, Z., and Edwards, G. "Heroin use in a Provincial Town, "Lancet, 1 (1968): 1189.

Ottenberg, Donald J., Rosen, Alvin. "Merging the Treatment of Drug Addicts into an Existing Program for Alcoholics," Quarterly Journal of Studies on Alcohol, 32 (1) March, 1971.

Perkins, I. H. "A Unique Approach to Hospital Treatment of the Narcotic Addict," Clinical Toxicology, 3 (4) 1970.

Ray, Marsh B. "The Cycle of Abstinence and Relapse Among Heroin Addicts," in The Other Side: Perspectives on Deviance, ed. Howard S. Becker, New York : Free Press, 1964.

Slotkin, E.J. Gateway: The First Three Years, Chicago: Gateway Houses Foundation, Inc., Illinois Drug Abuse Programs, 1972.

Vaillant, George E. "A Twelve Year Follow-up of New York Narcotics Addicts: Some Characteristics and Determinents of Abstinence," The American Journal of Psychiatry, $123(1966)$.

Volkman, R. and Cressey, D. "Differential Association and Rehabilitation of Drug Addicts," American Journal of Sociology, 69(2) (1963). 
Waldorf, Dan. "Life Without Heroin: Some Social Adjustments During Longterm Periods of Voluntary Abstention, "Social Problems, 4(1), Fall 1970.

Waldorf, Dan. "Social Control in Therapeutic Communities for Treatment of Drug Addicts," The International Journal of the Addictions, 6(1) 1971. 


\section{APPENDIX \\ INTERVIEW SCHEDULE - PART A}

1. Are you Male Female ?

2. How old are you?

3. What was the last grade you completed in school? (GED = 12)

$\begin{array}{lllllllllllllllllll}1 & 2 & 3 & 4 & 5 & 6 & 7 & 8 & 9 & 10 & 11 & 12 & 13 & 14 & 15 & 16 & \text { over } & 16\end{array}$

4. How many months were you a resident member of a long term drug treatment program?

5. Give the month and year when you left inpatient drug treatment.

6. After you completed inpatient treatment, were you an outpatient? Yes No

6A. If yes, how many months were you an outpatient?

7. How many attempts at treatment had you made before you succeeded?

8. Do you feel that any other type of treatment would have been successful for you? Yes No

$8 \mathrm{~A}$. If yes, what?

9. Do you feel you would have outgrown the need for drugs if you had not had treatment? Yes No

10. Do you feel that the drug treatment program from which you graduated created a significant change in your life? Yes No 10A. If yes, explain:

11. Do you currently have any regular contact with a drug treatment program? Yes No

11A. If yes, is this contact as a counselor outpatient other ?

11B. If other, explain: 
12. How many contacts a week do you have with this program?

13. Do you feel that regular contact with a drug treatment program is important in keeping you clean? IS NOW USED TO BE NEVER WAS

14. Was employment in the mental health field (including drug treatment) encouraged in your drug treatment program? Yes No

15. Do you feel employment in the mental health/drug treatment field was required for your graduation? Yes No

15A. Was this openly expressed or implied? EXPRESSED IMPLIED

16. Are you currently attending school? Yes $16 \mathrm{~A}$. If yes, what is your field of study?

No

17. Are you currently employed? Yes No

18. How many months have you been employed since discharge from your drug treatment program?

19. What type of work do you do?

20. Do you like your job?

21. What job skills do you have? 
INTERVIEW SCHEDULE - PART B

ANSWER THE FOLLOWING QUESTIONS ONLY IF YOU ARE, OR HAVE BEEN EMPLOYED IN THE MENTAL HEALTH/DRUG

TREATMENT FIELD.

22. How many months have you been employed in the mental health field?

23. How many months have you been employed in drug treatment specifically?

24. Had you ever done this type of work before you went through your treatment program? Yes No

25. Have you done any other type of work since you went through your treatment program? Yes No

$25 \mathrm{~A}$. If yes, what?

26. Do you feel that the employment of former addicts as counselors is important to the success of a drug treatment program?

Yes No

$26 \mathrm{~A}$. If yes, in what way?

27. Do you feel that the employment of former addicts as counselors in the drug treatment field is important to their success in staying clean? Yes No $27 \mathrm{~A}$. If yes, in what way?

28. Do you feel that your treatment program trained you for your job? Yes No

29. Do you feel that additional education or training would benefit you in your job? Yes No

30. Do you see your job as part of your own treatment? Yes No $30 \mathrm{~A}$. If no, did you ever see it that way? Yes No

31. Do you see your job as a way of staying in touch with people? Yes No

31A. If no, did you ever see it that way? Yes No 
32. Do you see your job as a way of staying in touch with the drug subculture? Yes No

$32 \mathrm{~A}$. If no, did you ever see it that way? Yes No

33. Do you see yourself as different from "straight" staff members where you work? Yes No

$33 \mathrm{~A}$. If yes, in what way?

34. Do you feel you have more dedication to treat addicts than "straight" staff members? MORE SAME LESS

35. Rank the following in the order of their importance to you. Number the MOST IMPORTANT as No. 1, least important as Number 8 , and so on to complete the following statement:

Working in the treatment field has helped me Make more money. Gain social status. Stay clean. Adjust to a new life style. Stay in touch with the drug subculture. Help others. Gain job security. Gain the opportunity to work with people. 